This is an author produced version of a paper published in Ecological Modelling.

This paper has been peer-reviewed and is proof-corrected, but does not include the journal pagination.

Citation for the published paper:

Lagergren, Fredrik; Jönsson, Anna Maria; Blennow, Kristina; Smith, Benjamin. (2012) Implementing storm damage in a dynamic vegetation model for regional applications in Sweden. Ecological Modelling.

Volume: 247, pp 71-82.

http://dx.doi.org/10.1016/j.ecolmodel.2012.08.011.

Access to the published version may require journal subscription.

Published with permission from: Elsevier.

Epsilon Open Archive http://epsilon.slu.se 


\title{
Implementing storm damage in a dynamic vegetation model for regional applications in Sweden
}

\author{
Fredrik Lagergren $^{\mathrm{a}^{*}}$, Anna Maria Jönsson ${ }^{\mathrm{a}}$, Kristina Blennow ${ }^{\mathrm{b}}$, Benjamin Smith $^{\mathrm{a}}$ \\ Manuscript published in Ecological Modelling 2012: 247 71-82 \\ ${ }^{a}$ Department of Physical Geography and Ecosystem Science, Lund University, \\ Sölvegatan 12, SE-223 62 Lund, Sweden \\ ${ }^{\mathrm{b}}$ Faculty of Landscape Planning, Horticulture and Agriculture Science, Swedish \\ University of Agricultural Sciences, Sundsvägen 4 - 6, SE-230 53 Alnarp, Sweden \\ * Corresponding author. Tel.: +46 46 2223976. E-mail address: \\ Fredrik.Lagergren@nateko.lu.se
}

\begin{abstract}
Wind is the dominant agent of damage in forests in Western Europe. Traditional winddamage models calculate a probability for damage or a critical wind speed at which damage occurs. However, in a dynamic vegetation model actual damage to stands and individual trees is needed to get a dynamical progression of the vegetation. We present a prototype for a new approach to modelling forest wind damage at the regional scale, which we incorporate within a dynamic vegetation model. The approach is based on knowledge from both empirical and mechanical models and calculates the damaged fraction of a cohort based on wind load and a sensitivity that depends on the current physical state and history of the cohort in relation to the ecosystem. The modelling concept has been developed, calibrated and evaluated for Swedish conditions but can be applicable to other similar areas with minor modification. Because of the stochastic nature of local wind load and the difficulty of describing the stand-level exposure, the ability to explain observed damage at stand level was low. Regional level variation in damage, which more depends on the wind load, was however explained reasonably well $\left(\mathrm{R}^{2}=0.43\right)$. We suggest that this is a useful concept for evaluating alternatives of forest management under different climate scenarios in the process of adaptation to future storm-damage risks.
\end{abstract}

\section{Keywords}

Dynamic vegetation model LPJ-GUESS; storm damage; windthrow; boreal forest; forestry 
Table 1. Abbreviations used in the article sorted in the order of appearance.

\begin{tabular}{|c|c|c|}
\hline Abbrev. & Explanation & Unit \\
\hline DVM & dynamic vegetation models & \\
\hline PFT & plant functional type & \\
\hline SNFI & $\begin{array}{l}\text { Swedish national forest inventory } \\
\text { year } 2004 \text {, the year from which the SNFI data were }\end{array}$ & \\
\hline$Y_{\mathrm{SNFI}}$ & taken & years \\
\hline$A_{\mathrm{SNFI}}$ & age a patch was assigned to have at $Y_{\mathrm{SNFI}}$ & years \\
\hline$P$ & county-average mean site productivity class & $\mathrm{m}^{3}$ of stem wood $\mathrm{yr}^{-1} \mathrm{ha}^{-1}$ \\
\hline$P_{\min }$ & minimum $\left(2.35 \mathrm{~m}^{3} \mathrm{yr}^{-1} \mathrm{ha}^{-1}\right) P$ among all counties & $\mathrm{m}^{3}$ of stem wood $\mathrm{yr}^{-1} \mathrm{ha}^{-1}$ \\
\hline$P_{\max }$ & maximum $\left(11.31 \mathrm{~m}^{3} \mathrm{yr}^{-1} \mathrm{ha}^{-1}\right) P$ among all counties & $\mathrm{m}^{3}$ of stem wood $\mathrm{yr}^{-1} \mathrm{ha}^{-1}$ \\
\hline$R$ & length of rotation & years \\
\hline$n_{\text {man }}$ & number of managed patches in the simulation & \\
\hline$n_{\mathrm{pnr}}$ & number of the current patch & \\
\hline$N$ & number of plants planted per area & individuals per hectare \\
\hline$\alpha$ & radiation use efficiency parameter & \\
\hline$k$ & light extinction coefficient & \\
\hline$A_{\text {ca }}$ & present total crown area of a patch & $\mathrm{m}^{2} \mathrm{ha}^{-1}$ \\
\hline$A_{\text {ca_th }}$ & $A_{\mathrm{ca}}$ before the most resent thinning & $\mathrm{m}^{2} \mathrm{ha}^{-1}$ \\
\hline$y_{\text {th }}$ & years from the last thinning & years \\
\hline WL & yearly wind load & \\
\hline$n$ & wind-direction sectors & \\
\hline$W_{\max }$ & daily maximum gust wind speed in sector $n$ & $\mathrm{~m} \mathrm{~s}^{-1}$ \\
\hline$W_{\text {perc }}$ & $W_{\max }$ for the chosen percentile & $\mathrm{m} \mathrm{s}^{-1}$ \\
\hline $\begin{array}{l}\text { RCA3 } \\
\text { EI }\end{array}$ & Rossby Center regional climate model & \\
\hline gridcell & exposure index at the grid-cell level & \\
\hline$A$ & average compartment area in a county & ha \\
\hline$f_{\text {for }}$ & forest fraction in a county & \\
\hline$h$ & tree height & $\mathrm{m}$ \\
\hline$h_{\text {patch }}$ & $\begin{array}{l}\text { average patch } h \\
\text { effective } h \text { ( } 1 \text { for connifers, } 0.5 \text { for broad-leafed }\end{array}$ & $\mathrm{m}$ \\
\hline$h_{\mathrm{E}}$ & trees) & $\mathrm{m}$ \\
\hline$h_{\mathrm{disp}}$ & displacement height & $\mathrm{m}$ \\
\hline$h_{\text {gridcell }}$ & average grid-cell $h$ & \\
\hline EI_patch & exposure index at the patch level & \\
\hline$f_{\text {RAND }}$ & random factor in the calculation of EI_patch & \\
\hline HI_patch & height index at the patch level & \\
\hline
\end{tabular}




\begin{tabular}{|c|c|c|}
\hline RSI_patch & root stability index for a patch & \\
\hline$B_{\text {root }}$ & current fine-root biomass & $\mathrm{kg} \mathrm{m}^{-2}$ \\
\hline$B_{\text {root_th }}$ & $B_{\text {root }}$ at the time of the most recent thinning & $\mathrm{kg} \mathrm{m}^{-2}$ \\
\hline$a$ & parameter in the RSI_patch equation & \\
\hline$b$ & parameter in the RSI_patch equation & \\
\hline FSI_patch & frozen soil index for a patch & \\
\hline$N_{\text {frozen }}$ & number of days with frozen soil in January-March & \\
\hline$c$ & parameter in the FSI_patch equation & \\
\hline HI_cohort & height index at the cohort level & \\
\hline AI_cohort & allometric-relationship index at cohort level & \\
\hline$k_{h}$ & $\begin{array}{l}\text { height related parameter in the AI_cohort equation } \\
\text { diameter related parameter in the AI_cohort }\end{array}$ & $\mathrm{m}$ \\
\hline$k_{d}$ & equation & $\mathrm{cm}$ \\
\hline$k_{\text {species }}$ & species related parameter in the AI_cohort equation & \\
\hline$d_{\text {cohort }}$ & cohort mean diameter & $\mathrm{cm}$ \\
\hline SI_cohort & total sensitivity to wind damage for a cohort & \\
\hline DF_cohort & damaged fraction of a cohort & \\
\hline$m$ & calibration factor of DF_cohort & \\
\hline
\end{tabular}

\section{Introduction}

Wind is one of the major natural disturbance factors of forests together with fire and insect pests (Schelhaas et al., 2003). Western Europe has experienced a number of storms in the last few decades that have caused wind throws of the same magnitude as national yearly harvests, e.g. 1999 in France and 2005 in Sweden, (Gardiner et al., 2010). In addition to the direct effect on the forests composition and the economy of forest owners, the impacts can cascade through society (Gardiner et al., 2010), may affect the carbon balance (Lindroth et al., 2009) and result in secondary impacts from bark-beetle damage (Schelhaas et al., 2003).

There are some concerns that climate change will increase the risk for destructive winds (Hoyos et al., 2006) but for Europe the climate model projections show no consistent increase (Nikulin et al., 2011). Wind-damage simulations indicate, however, that indirect effects of climate change can make the forest more sensitive to strong winds as long as the management regime remains unadapted; e.g. if trees grows taller, if the trees are stressed by other weather extremes or from not being acclimatized to the new climate, or by absence of ground frost (Blennow et al., 2010).

The interest for storm-damage studies has commonly increased after major events as can be seen for Europe after the big storms 1969-1972 (Oliver and Mayhead, 1974; Persson, 1975). Models of storm damage have historically been developed independently within two rather different categories. Empirical wind-throw models are built on the 
relationships between observed wind throw and tree, stand and landscape attributes (e.g. Lanquaye-Opoku and Mitchell, 2005; Lohmander and Helles, 1987; Scott and Mitchell, 2005; Valinger and Fridman, 1999). They predict a proportion of stand damage to a specified level of confidence. Models of this kind can be useful for predicting probability for damage in the region and under the conditions for which they have been calibrated but they are not generally applicable for extrapolation to other regions or a changed climate. Another shortcoming with such models is that they are often based on inventoried damage in conjunction with one major storm, which means that they have no connection between wind speed and damage. The second category, mechanistic models, use maximum resistance for up-rooting or stem breakage based on tree-winching experiments (e.g. Peltola et al., 2000) and the wind loading imposed on trees from wind tunnel data (e.g. Rudnicki et al., 2004) to calculate a critical wind speed above which the wind load exceeds the resistance. In combinations with models to scale down wind data to single forest edges (e.g. Blennow and Sallnäs, 2004), such a combination, which explicitly represent the main physical processes involved in in tree wind damage, will form a mechanistic model (Gardiner et al., 2008, review). To run these models a very detailed description of the trees, forest and landscape is needed limiting their application at large-scales. Further, the output of this type of models is typically a critical wind speed for overturning or stem-break or a probability of exceeding such wind speed, whereas the actual incidence of wind throw, and its spatial variability, would be more useful metrics for describing the impacts of storms on forests at the landscape scale.

Dynamic vegetation models (DVMs, all abbreviations used in the article are given in Table 1) attempt to simulate the development and dynamics of vegetation in response to variation in weather or climate. The different species or plant functional types (PFTs) that represent the vegetation in the model are differentiated by parameters that influence the effect of climate or vegetation state on the growth and allocation of individuals, and regeneration and mortality in the species or PFT. Disturbances are an important factor influencing mortality and thereby the composition and biomass of vegetation, as well as competition between size cohorts (if represented), species and PFTs in these models. The disturbances can for example be represented as random events of unspecified cause with a prescribed expected return time. Alternatively, they may represent specific disturbance agents, and could be triggered by weather and simulated ecosystem state. For fire disturbance the development of mechanistic representations has come relatively far (Kloster et al., 2010; Lehsten et al., 2010). For wind and insect out-breaks, mechanistic implementations are still rare (Seidl et al., 2011).

Sweden is a country that has a long national-forest inventory record starting from 1923 (http://www.slu.se/en/collaborative-centres-and-projects/swedish-national-forestinventory/, accessed 8 July. 2012) and also long and comparatively detailed records on wind damage (Nilsson, 2008; Nilsson et al., 2004) and is therefore a suitable reference case for the development of a mechanistic representation of wind disturbances suitable for incorporation in a DVM. The forests in Sweden are intensively managed and the natural disturbances in a DVM therefor have to be complemented by representation of forest management events to properly emulate the vegetation development. There is also a big interest in the Swedish forestry of climate adaptation and how to manage forests to 
reduce the risk of devastating damages, as recently experienced in conjunction with storms in 2005 and 2007.

The aim of this study is to develop a modelling concept that can be used to address a wide range of questions that are relevant for adapting the forest management to the future risk for storm damage. For this purpose a wind-damage model with a mechanistic representation of the wind-sensitivity, and a vegetation model in which the trees can respond to climate and management dynamically, with feedback of simulated wind disturbances, are needed. From literature research we have developed an empirical winddamage module with mechanistic features, which is mainly intended for regional scale applications. It has then been connected to the well-established LPJ-GUESS DVM, calibrating and evaluating the resultant model against observed wind damage records for Sweden.

\section{Material and methods}

Forest vegetation model LPJ-GUESS

We employed LPJ-GUESS (Smith et al., 2001), a dynamic vegetation model optimised for regional applications, which also incorporates a representation of the structure of the forest similar to gap models (Prentice et al., 1993; Shugart, 1984). The model shares the representation of biochemical and hydrological processes of the global LPJ-DGVM model (Gerten et al., 2004; Sitch et al., 2003), which, however, employs a simpler, areabased representation of the vegetation. LPJ-GUESS simulates vegetation structure and composition in response to spatial and temporal variation in temperature, precipitation, incoming shortwave radiation and soil physical properties across a grid. Atmospheric $\mathrm{CO}_{2}$ concentration is an additional input variable to the model. The vegetation of each simulated grid cell, typically corresponding to an area several kilometres on a side, i.e. a forest landscape, is represented by a number of replicate patches that all have the same climate and soil type but differs in their disturbance history. We have used climate data with a $50 \times 50 \mathrm{~km}$ resolution (see below), which accordingly is the grid-cell size in the present study. The patches can be seen upon as sample stands in the grid cell that each represent an area of a small forest stand (c. 0.1 ha). In the patches the vegetation is represented by cohorts, which are age/size-classes of different plant functional type (PFT) or species, in which the differences among individuals are averaged to give a single value for each cohort of a given PFT or species in each patch at a given time step (a day or, for structural properties, a year). PFTs or species are distinguished by different static parameters governing limits to the climate space in which the species is able to regenerate or survive, as well as phenology (evergreen/summergreen), physiology of photosynthesis, allometric relations and life history characteristics. In the present study, LPJ-GUESS was set up to represent all major tree species in Sweden, as well as a $\mathrm{C}_{3}$ grassy understorey (Miller et al., 2008).

Simulation of the managed forest in Sweden

In Sweden $91.6 \%$ of the forest land is managed and the remaining part is either formally protected or voluntary set aside for conservation purposes (SwedishForestAgency, 2011). 
With such high fraction of managed forest it was important to complement the random disturbance and natural establishment scheme of LPJ-GUESS with a management scheme that is representative for Swedish forestry. Otherwise the default setting would create a "potential forest", in dynamic equilibrium with the climate and the random disturbances, but this is not representative of the actual forests, which are largely composed of commercially favoured native species, typically Norway spruce and Scots pine, in even aged stands.

To simulate the actual present-day composition of the forests in Sweden with sufficient accuracy to enable wind damage to be simulated and compared with observations, we employed county based compilations of the species composition and age distribution from the Swedish national forest inventory (SNFI). With subdivisions of some larger actual counties there are 30 such "counties", each containing between 0.5 and $9 \%$ of the total forest area of Sweden. Within each county there were 1-33 grid cells, with a total sum of 186 for the entire Sweden. Data from 2004 ( $\left.Y_{\mathrm{SNFI}}\right)$ were used to initialise the model, as this was the year preceding the most devastating storm for the Swedish forests in history. The fractional coverage of four species-classes was used; Scots pine (Pinus Sylvestris), Norway spruce (Picea abies), boreal broad-leafed (Betula pendula, B. pubescens, Alnus incana, A. glutinosa and Populus tremula) and temperate broad-leafed (Fagus sylvatica, Quercus robur, Fraxinus excelsior, Ulmus glabra, Tilia cordata and Carpinus betulus). The reason for using these classes is that SNFI does not report the area coverage on species level but for seven species-classes (Scots pine, Norway spruce, $P$. contorta, mixed conifers, mixed forest, boreal broad-leafed and temperate broad-leafed), which we have simplified to four. The SNFI age data are given as area covered by different age classes, which are 3-20 years long (age 0-3, 3-10, 10-20 years etc.). To facilitate the initiation of the patches these classes have been interpolated to fractions in 1-year classes. When initializing a grid cell, each patch was assigned a species class and an age at $Y_{\mathrm{SNFI}}\left(A_{\mathrm{SNFI}}\right)$ in such a way that the distribution of ages and species classes among the patches was the same as in the SNFI data. That the different species within a county could have different age distributions was not taken into account. Depending on the county-average mean site productivity class $\left(P, \mathrm{~m}^{3}\right.$ of stem wood $\left.\mathrm{yr}^{-1} \mathrm{ha}^{-1}\right)$ from SNFI, a length of rotation ( $R$, years) was calculated as:

$$
\mathrm{R}=125-60 \frac{P-P_{\min }}{P_{\max }-P_{\min }}
$$

where $P_{\min }$ and $P_{\max }$ are the minimum $\left(2.35 \mathrm{~m}^{3} \mathrm{yr}^{-1} \mathrm{ha}^{-1}\right)$ and maximum $\left(11.31 \mathrm{~m}^{3} \mathrm{yr}^{-1} \mathrm{ha}^{-}\right.$ $\left.{ }^{1}\right) P$ among all counties. This gave $R$ between 65 and 120 years, which is consistent with recommendations for coniferous forests in Sweden (Skogsstyrelsen, 1989a, b). The

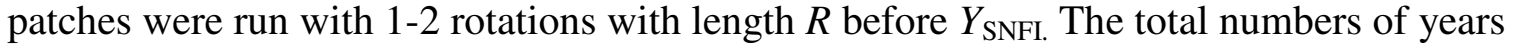
at which clear-cuts were simulated for a patch were given by the following equations:

$$
Y_{\text {cut1 }}=Y_{\mathrm{SNFI}}-A_{\mathrm{SNFI}}-R
$$

$Y_{\mathrm{cut} 2}=Y_{\mathrm{SNFI}}-A_{\mathrm{SNFI}}$ 


$$
\begin{aligned}
& Y_{\text {cut3 }}=Y_{\mathrm{SNFI}}+1+\frac{n_{\mathrm{man}}-n_{\mathrm{pnr}}}{n_{\mathrm{man}} / \mathrm{R}} \\
& Y_{\mathrm{cut} 4}=Y_{\mathrm{cut} 3}+\mathrm{R}
\end{aligned}
$$

where $n_{\mathrm{man}}$ is the number of managed patches in the simulation and $n_{\mathrm{pnr}}$ is the number of the current patch $\left(0-n_{\mathrm{man}}\right)$ where the patches are ordered after $A_{\mathrm{SNFI}}$. The rationale behind Eq. 2.3 is to have the cuttings evenly distributed in time even when there are patches with $A_{\mathrm{SNFI}}$ higher than $R$. Before the first cut the patches were initialised in the standard manner of LPJ-GUESS as potential vegetation subject to random disturbances with an expected return time of 100 years. After the first cut in each patch no further random disturbances were allowed, but the density-dependent self-thinning was still activated. Forest that is older than $R+25$ years was assumed to represent unmanaged vegetation such as nature reserves and was simulated without management. The total number of patches was set to 150 in the simulations for the present study.

After a simulated clear-cut new trees were established mimicking planting. The number of plants per area ( $N$, individuals per hectare) was a function of productivity in the same manner as for the rotation length:

$$
N=1500+1500 \frac{P-P_{\min }}{P_{\max }-P_{\min }}
$$

In the broad-leafed classes a mix of species was "planted" in the patch (in boreal broadleafed B. pendula $25 \%$, B. pubescens 50\%, A. incana $10 \%$ and P. tremula 15\%; in temperate broad-leafed $F$. sylvatica $40 \%, Q$. robur $50 \%$ and $F$. excelsior $10 \%$ ). Each planted species creates one cohort in the patch. After the first year following planting, all species could regenerate naturally, which means that new cohorts are created.

Table 2. The age, in relation to the length of rotation $(R)$, at which thinning is done and what fraction of the individuals that are removed. The scheme is different for $R$ longer or shorter than 100-years.

\begin{tabular}{ll}
\hline \multicolumn{2}{l}{$R>100-\mathrm{yr}$} \\
Age & Strength \\
\hline $0.10 R^{\mathrm{a}}$ & $10 \%$ \\
$0.35 R$ & $30 \%$ \\
$0.65 R$ & $30 \%$ \\
\multicolumn{2}{l}{$R<100-\mathrm{yr}$} \\
Age & Strength \\
\hline $0.10 R^{\mathrm{a}}$ & $10 \%$ \\
$0.30 R$ & $25 \%$ \\
$0.50 R$ & $25 \%$ \\
$0.70 R$ & $25 \%$ \\
\hline
\end{tabular}

\footnotetext{
${ }^{\mathrm{a}}$ Pre-commercial thinning in which $10 \%$ of planted and $90 \%$ of not-planted individuals are removed.
} 
Thinning was modelled at ages corresponding to fixed fractions of $R$ (Table 2) based on standard management of conifers in Sweden (Skogsstyrelsen, 1989a, b). The thinning strength was the same for all cohorts in a patch, which means that the strength could refer to both fraction of basal area and number of stems removed. The first thinning was precommercial at which $90 \%$ of the individuals in not-planted cohorts were removed.

If wind damage was simulated to occur on a patch (see below) there were three options for management action; if the damaged volume was less than $4 \mathrm{~m}^{3} \mathrm{ha}^{-1}$ the trees were left, if there was more than $4 \mathrm{~m}^{3} \mathrm{ha}^{-1}$ wind throws but less than $50 \%$ of the total volume was damaged the damaged trees were harvested and if the damage was more than $50 \%$ all trees on the patch were harvested and a new generation was initialized.

To dynamically initiate the forest to the actual state over several decades for accurate assessment of storm damage it is also important that the forest growth is reasonable well simulated. It has previously been shown that LPJ-GUESS fails to reproduce the step trend of declining forest productivity with latitude that can be found in Scandinavia (Koca et al., 2006; Zaehle et al., 2006). The likely explanation is the absence of nutrient limitation on plant production in the model (Koca et al., 2006). Zaehle et al. (2006) compensated for this bias by adjusting the radiation use efficiency parameter $(\alpha)$ in the model to yieldtable data. Similarly, we used $P$ for a linear scaling of $\alpha$ :

$$
\alpha=0.30+0.25 \frac{P-P_{\min }}{P_{\max }-P_{\min }}
$$

Under the development of the model we found that after a thinning there was an immediate stimulation of the stand-level stem biomass growth whereas the general consensus from thinning studies is that a decline is expected for some years (Näslund, 1971). This discrepancy is explained by the simplified representation of allocation processes and canopy architecture in the model. Hale (2003) found that the light extinction coefficient $(k)$ of Beer's law is strongly reduced after thinning Sitka spruce $(P$. sitchensis (Bong) Carr.). A thinning-reduction factor was therefore applied to $k$ :

$$
k_{\text {new }}=k\left(A_{\text {ca }} / A_{\text {ca_th }}\right)^{\left(1 /\left(1+y_{\text {th }}\right)\right)}
$$

where $A_{\mathrm{ca}}$ is the present total crown area of a patch, $A_{\text {ca_th }}$ is $A_{\text {ca }}$ before the most resent thinning and $y_{\text {th }}$ is years from the last thinning.

\section{Overview of the wind damage module}

We adopted concepts from existing mechanistic and empirical models to construct an empirical wind damage module with mechanistic features, suitable for implementation in LPJ-GUESS. The model has been built from known relationship to predisposing (effecting the sensitivity) and triggering (wind load and absence of frozen soil) factors but sometimes it has been hard to get numbers on how the factors are related to specific wind damaged fraction. For some of the most uncertain parameters we have therefor also done a sensitivity test. The concept of the model is presented in Figure 1. The damaged fraction, which is calculated each year on the cohort level, is fed to the vegetation- 
dynamic module of LPJ-GUESS. The module runs in the end of the year and has also routines for establishment, mortality and the management. The storm damage is applied before management takes place and the thinning routine subtracts the total storm-damage fraction within a path since previous thinning from the prescribed thinning strength. In LPJ-GUESS the patches don't have any spatial relationship to each other, which means that some of the mechanistic aspects had to be simplified. Topography and soil properties are aspects that are included in some wind damage models, which were left out as they were considered of less importance and hard to quantify at the regional scale of this study.

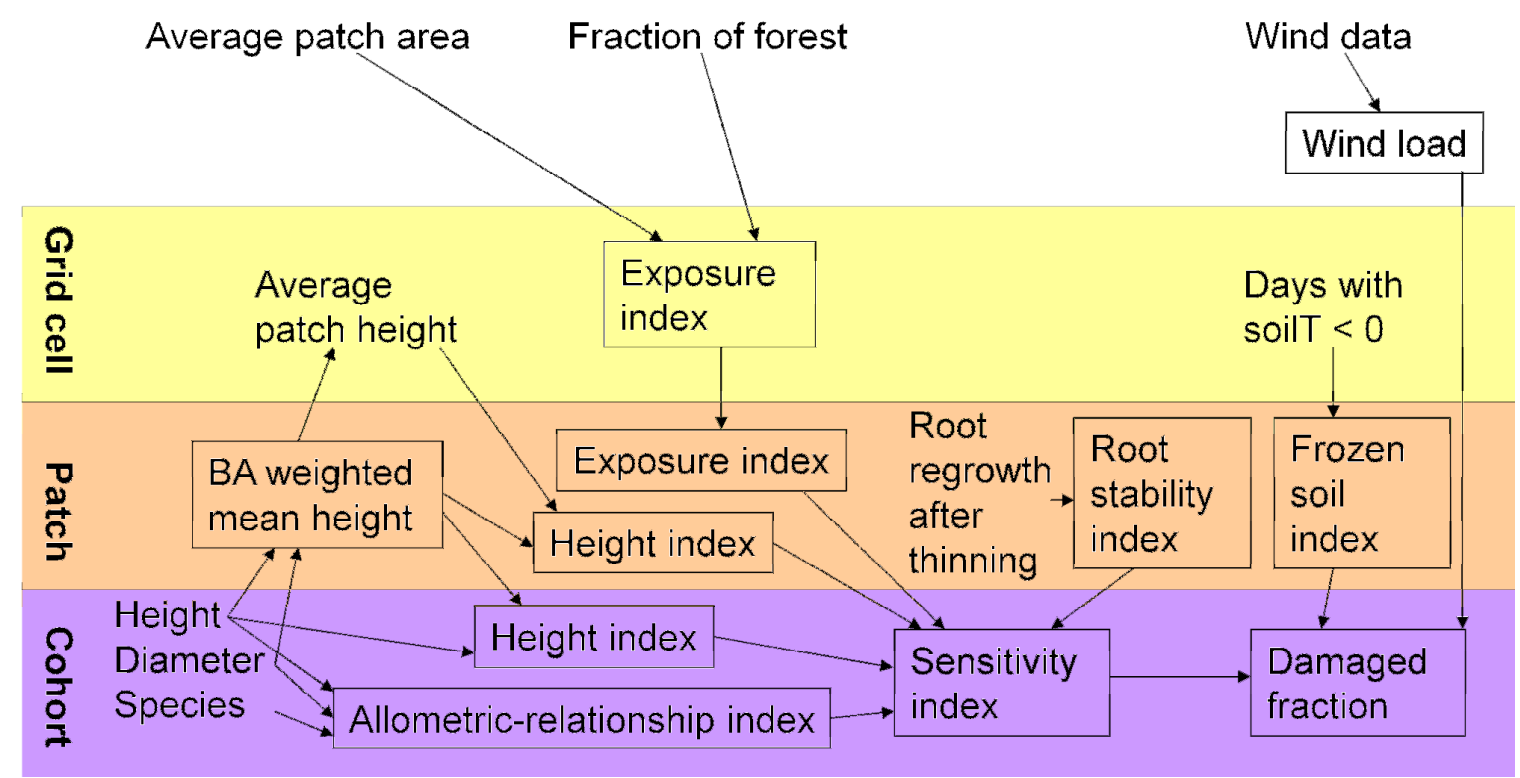

Figure 1. Concept of the LPJ-GUESS wind damage module. Grid cell, Patch and Cohort represent the three hierarchical levels within GUESS. Outside the shaded area are input and external processes. The module takes external data of wind load, average patch area and fraction of forest, and use the state of the vegetation to calculate the damaged fraction of a cohort, which is then fed back to the vegetation dynamics of LPJ-GUESS.

\section{Wind load}

As the damage from wind is not linearly related to wind speed (Klawa and Ulbrich, 2003) and to be able to distribute the damage to different patches in a realistic way (see below) a concept of wind load was used. Yearly wind load (WL) in six different wind-direction sectors $(n)$ for each grid cell is calculated according to Klawa and Ulbrich (2003) as:

$\mathrm{WL}_{n}=\sum_{d=1}^{365}\left(\frac{W_{\max n}}{W_{\text {perc }}}-1\right)^{3} \quad$ if $W_{\max n}>W_{\text {perc }}$

Where $W_{\max n}$ is the daily maximum gust wind speed in sector $n$ and $W_{\text {perc }}$ is $W_{\max }$ for the chosen percentile. $W_{\text {perc }}$ was determined individually for each grid cell as the $W_{\max }$ value of the chosen percentile for the 1961-1990 period. Different percentiles and wind data were tested and we also tried to use a common average $W_{\text {perc }}$ for all grid cells. We found 
that the $99.5 \%$ percentile determined locally from $W_{\max }$, which was obtained from the daily maximum value of gust wind speed (based on 8 three hour periods) at $10 \mathrm{~m}$ height from the RCA3-ERA40-data we used (see below), was best to use (see supplementary content S1).

\section{Exposure index at grid-cell level}

The exposure index at the grid-cell level (EI_ gridcell) is intended to reflect the length of exposed edges per area unit. Generally speaking EI_ gridcell is related to the fragmentation of the forest, the shape of the units and the average size of the units of the forest. We assume that there is no systematic pattern of forest unit shape over Sweden and disregard this aspect. Fragmentation is difficult to express quantitatively, but with a lower fraction of forest in the landscape it is reasonable to expect an increase in the proportion of edges adjoining a different land-use type. It can be shown that the total edge length in a given area is proportional to $A^{-0.5}$ were $A$ is the compartment area. Forest fraction $\left(f_{\text {for }}\right)$ and average $A$ has been implemented in EI_ gridcell as:

EI_gridcell $=\frac{\left(1-0.8 f_{\text {for }}\right) \times 2}{\sqrt{A}}$

The data on $f_{\text {for }}$ were taken from the county-based compilations from the Swedish National Forest Inventory and $A$ was assigned the county based average unit size of "clear-cut reports" to the Swedish Forest Agency for the years 2001, 2002, 2006 and 2007 (SwedishForestAgency, 2002, 2003, 2007, 2008), selected as recent years not dominated by storm clearings.

\section{Average patch height}

The average patch height $\left(h_{\text {patch }}\right.$ (meter)) is basal area weighted for best representation of the dominating tree size. As the storms typically occur in winter when the deciduous trees have no leaves (see supplementary content S2), a concept of "effective tree height" $\left(h_{\mathrm{E}}\right)$ was introduced, setting $h_{\mathrm{E}}$ for deciduous trees to $0.5 h$ in the calculation of $h_{\text {patch }} . h_{\text {patch }}$ is used to estimate the shelter a tree in a patch gets from the other trees within the patch and how much shelter the patch gives to surrounding patches. An argument against using $h_{\mathrm{E}}$ is that Kohnle and Gauckler (2003) found no differences of losses between spruce in pure stands or mixed with deciduous species when they analysed storm damage in a periphery district of the 1999 storm in south-western Germany. Lindroth (1993) has, however, shown that the displacement height $\left(h_{\text {disp }}\right)$ is roughly $50 \%$ of bare deciduous trees compared to fully vegetated ones. $h_{\text {disp }}$ is such as the distribution of shearing stress over the tree's height is aerodynamically equivalent to the imposition of the entire stress at height $h_{\text {disp }}$ (Monteith and Unsworth, 1990). It is therefore reasonable to assume that trees without leaves have about the same sheltering effect as a half as high trees with needles on. A test of the sensitivity of different values of $h_{\mathrm{E}}$ for broad-leafed trees on the regional level of storm damage simulations was also done.

The average grid-cell height $\left(h_{\text {gridcell }}\right)$ was subsequently calculated as an arithmetic mean of $h_{\text {patch }}$ for all patches. The use of $h_{\mathrm{E}}$ has implication if management alternatives with mixed patches of evergreen and deciduous species are run. 
Exposure index at the patch level

The exposure index at the patch level (EI_patch) is intended to reflect how much a patch is exposed to damaging wind from each of the six wind sectors $(n, 1-6)$. In reality different stands are differentially exposed to wind damage from different directions because of the slope and height of the surrounding stands; similar stands can experience a wide range of damages depending on the exposure (e.g. Lohmander and Helles, 1987; Persson, 1975). As the patches in a grid cell don't have any explicit localisation relative to each other or to the general landscape properties, exposure was not treated in a mechanistic way. For a realistic distribution of the fraction of damage in different patches a random factor $\left(f_{\mathrm{RAND}}, 0.25-1\right)$ is instead simply included in the calculation as:

$$
\text { EI_patch }{ }_{n}=\text { EI_gridcell } \times f_{\text {RAND }}
$$

In a simulation Eq. 8 is run once for each patch so that EI_patch ${ }_{n}$ is constant over the simulation years.

\section{Height index at the patch level}

The height index at the patch level (HI_patch) is an index of how much the vegetation of a certain patch emerges above the general forest canopy:

$$
\text { HI_patch }=\frac{h_{\text {patch }}-b_{\text {gridcell }}}{30}+0.5
$$

Eq. 9

The function is designed to give a linear response to both $h_{\text {patch }}$ and $h_{\text {gridcell }}$ in the range 0 1.5 (values above 1.2 are quite extreme) for heights in Swedish forests. In the WINDA system of models for wind damage probability (Blennow and Sallnäs, 2004), an edge to a neighbouring patch is considered if the patch is at least $10 \mathrm{~m}$ higher than its neighbour. Lohmander and Helles (1987) modelled that the fraction damaged in $20 \mathrm{~m}$ high spruce forests in Denmark, was reduced from $21-25 \%$ to $1-5 \%$ as the height of the height of the neighbouring stand in the direction of the wind was increased from 10 to $35 \mathrm{~m}$. In our regional model the patches were not spatially defined and we don't kept track on which stands had common edges, instead the patch height was compared to the average height for the grid-cell.

\section{Root stability index}

Several studies have shown that the trees remaining after a thinning event suffer a reduction in stability (e.g. Lohmander and Helles, 1987; Ni Dhubhain et al., 2001). One mechanism for this is that the web of living roots that anchor the trees is broken (Nielsen, 1995). Another is that trees that have grown in a dense stand favour more height growth than diameter growth and a period of acclimation is needed to grow to a more stable shape (Burton and Smith, 1972; Farrar, 1961). The root stability index for a patch (RSI_patch) is calculated yearly from the current fine-root biomass ( $\left.B_{\text {root }}\right)$ and $B_{\text {root }}$ at the time of the most recent thinning $\left(B_{\text {root_th }}\right)$ : 
RSI_patch $=a+\frac{(1-a)}{b}\left(1-\frac{B_{\text {root }}}{B_{\text {root_th }}}\right)$

Eq. 10

$a$ is a parameter of the sensitivity of an unthinned stand relative to a newly thinned stand; which was set to $0.3 . b$ is the thinning strength where RSI_patch $=1$ (assuming that $B_{\text {root }}$ / $B_{\text {root_th }}$ immediately after the thinning is equal to 1 - thinning strength); and was set to 0.35 as the recommended thinning strength in Sweden rarely exceeds this value (Skogsstyrelsen, 1989a, b). Ni Dhubhain et al. (2001) showed that thinned stands of Sitka spruce had up to two times higher probability for wind throw than unthinned stands. Lohmander and Helles (1987) modelled that the wind thrown fraction after the 1981 storm was reduced exponentially from $42-56 \%$ the year after thinning to $22-23 \%$ after 10 years in $20 \mathrm{~m}$ high Danish spruce forests. In Tönnersjöheden research area in southern Sweden, Persson (1975) found that the fraction of wind damage was about three times higher in stands that had been thinned within one year before the 1969 storm than in stands that had been thinned 5-years earlier. Valinger and Fridman (2011) found that stands which had been thinned within five years from the severe storm in Sweden 2005 had $57 \%$ higher risk of being classified as damaged compared to unthinned stands. Based on these studies we suggest that 0.3 is a reasonable value of $a$, but as the uncertainty is substantial we also test the model's sensitivity to the parameter. We use the re-growth of root biomass instead of years since thinning to make the index depending on the speed at which the trees re-occupy the soil.

\section{Frozen soil index}

The frozen soil index (FSI_patch) reflects how much more sensitive trees are to uprooting or stem breakage without the occurrence of frozen soil, assuming that breakage is needed to damage trees on frozen soil. The index is based on the number of days with frozen soil in January-March $\left(N_{\text {frozen }}\right)$ :

$$
\text { FSI_patch }=c+(1-c)\left(90-N_{\text {frozen }}\right) / 90
$$

$c$ is a parameter that express how sensitive the trees on a frozen soil are compared to on an unfrozen; and was set to 0.7. In the model, the soil was assumed to be frozen if the internally-calculated soil temperature at $25 \mathrm{~cm}$ depth was below $0^{\circ} \mathrm{C}$. The difference in wind speed needed for stem breakage or uprooting depends on tree species and the shape of the tree (Peltola et al., 1999b). For trees that are slender for their height, the required wind speed is about the same, while less slender trees with a lower height to diameter ratio require c. $30 \%$ higher wind speeds for breakage than for uprooting (Peltola et al., 1999b). As we use wind load calculated with a cubic threshold equation (Eq. 6) instead of wind speed, the numbers of wind speed for uprooting to breakage ratios cannot be directly interpreted, but we consider that a $30 \%$ reduction of the sensitivity is reasonable (which means that $c=0.7$ ). We also tested to model $c$ as a function of species, diameter and height by using HWIND data from Peltola et al. (1999b) and ForestGales simulations, using the quotient between critical wind speed for uprooting and stem breakage, which corresponds to $c$ as a proxy. As there was no consistent relationship 
between the quotient and diameter-height ratio it was decided to use a constant value of $c$. As the value of $c$ is uncertain it was also included in the sensitivity test.

Height index at the cohort level

The height index at the cohort level (HI_cohort) is an index of how much a given cohort emerges above the other cohorts in a patch.

$$
\text { HI_cohort }=\frac{h_{\text {chort }}-h_{\text {patch }}}{30}+1
$$

For traditionally-managed forest the index has little significance as the dominant cohort in the patch will get a value close to 1 . In unmanaged forests or continuous cover forestry, however, the index implies that the highest cohorts in a patch will be most sensitive to storm damage and that a cohort of a certain height will be more sensitive to damage if its neighbours are shorter than itself. Whether continuous-cover forests are more or less sensitive to storms than clear-cut systems is a matter of discussion in Sweden (e.g. Hagner, 1996; Oleskog et al., 2008), but there are few empirical data from Swedish conditions to support either view.

\section{Allometric-relationship index for the cohorts}

The allometric-relationship index at cohort level (AI_cohort) is an index of how sensitive the trees in a cohort are to wind throw without taking other trees, patches or topography into account:

$$
\text { AI_cohort }=\frac{h_{\text {cohort }}-k_{b}}{d_{\text {cohort }}+k_{d}} k_{\text {speicies }} \quad \text { Eq. } 13
$$

The function gives a linear dependency of $h_{\text {cohort }}$ above $k_{h}$, which is a constant minimum height for occurrence of wind damage (set to $5 \mathrm{~m}$ ). This value was approximately achieved by extrapolating the relationships found by Ni Dhubhain et al. (2001). $d_{\text {cohort }}$ is cohort mean diameter $(\mathrm{cm})$ and $k_{d}$ is a parameter (set to $12 \mathrm{~cm}$ ) that reduce the dependency of the diameter. Compared to e.g. the relationships from the HWIND model (Peltola et al., 1999a) the value is high but there are also studies where no dependency of $h / d$ has been found (Valinger and Fridman, 2011) and accordingly we used a conservative value of $12 \mathrm{~cm} . k_{\text {species }}$ is a species-dependent constant, set to 1.0 for Norway spruce, 0.5 for Scots pine and 0.1 for the remaining species. These values are approximations from the models of Valinger and Fridman (1999) for the difference in probability of snow and wind damage, using the higher range of tree sizes to disregard the influence of snow damage, which dominates when the forest is young. Valinger and Fridman (2011) also got similar results when they evaluated the risk for damage after the 2005 storm in Sweden, namely $46 \%$ of the spruce risk for pine and $2 \%$ for broad leafed. From the HWIND runs by Zeng et al. (2010) it can be interpreted that the sensitivity of pine is $62 \%$ of that of spruce, but this number does not take into account that spruce often grow on soils that promote less stable trees. By analysing storm damage in a periphery district of the 1999 storm in south-western Germany, Kohnle and Gauckler (2003) found that the vulnerability for some hard-wood species was 6-20\% of the value for spruce. Numerous 
studies have shown that the storm damage is highly correlated the relationship between tree height and stem diameter (e.g. Peltola et al., 1999b; Scott and Mitchell, 2005; Valinger and Fridman, 1999). AI_cohort is related to the inverse of the critical wind speed required for breakage or uprooting that is used in many mechanistic wind-damage models (for review see Gardiner et al., 2008).

\section{Total sensitivity to wind damage for a cohort}

The total sensitivity to wind damage (SI_cohort) in the six wind sectors is calculated with a multiplicative function:

SI_cohort ${ }_{n}=$ EI_patch ${ }_{n} \times$ HI_patch $\times$ RSI_patch $\times$ HI_cohort $\times$ AI_cohort $\quad$ Eq. 14

\section{Damaged fraction of a cohort}

To finally assess the damaged fraction of the single cohorts (DF_cohort) the predisposition factor (SI_cohort) is mulitiplied with the triggering factors:

DF_cohort $=\sum_{n=1}^{6}\left(\right.$ SI_cohort ${ }_{n} \times$ WL ${ }_{n} \times$ FSI_patch $\left.\times m\right)$

Eq. 15

DF_cohort is restricted to be between $0-1, m$ is a calibration factor (see Calibration and validation below).

\section{Climate data}

LPJ-GUESS was driven by data from the Rossby Center regional climate model RCA3 (Samuelsson et al., 2011) run with ERA40 boundary conditions for the period 1961-2008 with a spatial resolution of $50 \times 50 \mathrm{~km}$ of the output. For spin-up of soil carbon and water conditions in dynamic equilibrium with the climate, the LPJ-GUESS simulations started 1701 and the 1961-1990 climate data were repeated until the historical period started.

\section{Calibration and validation}

For calibration and evaluation of the model, a data-set of yearly county-level wind damage statistics for Sweden for 1900-2007 was used (Nilsson, 2008; Nilsson et al., 2004). The calibration factor ( $m$ in Eq. 15) was set to 9.35, after tuning it so that the simulated total wind damage in Sweden for 2005 (the year with the most severe damage) matched the total inventoried damage. Remaining years were used for validation of the model.

The mechanistic parts of the model were evaluated by data on observed damage by the 1969 storm at Tönnersjöheden research station (Persson, 1975). This dataset includes damage fraction, time and strength of last thinning as well as stand characteristics of research plots ranging from $0.1-1$ ha (median 0.25 ha). We also compared the mechanistic outcome of our model with the model of Lohmander and Helles (1987) which was based on a detailed study of stand level damage after the 1981 storm over Denmark. The Lohmander and Helles model employs similar input variables as our model. 
For the parameters selected for the sensitivity test, regressions between observed and simulated grid-cell level damage was used.

\section{Results}

Evaluation of the mechanistic parts of the wind damage model

The model was not successful in describing the variation in observed stand damage within the Tönnersjöheden research area in 1969 (Figure 2). Comparing the relationship of the wind sensitivity to forest parameters in the Lohmander and Helles (1987) model and our storm module showed that the former model has steeper responses to these variables (Figure 3). The sensitivity scale in the figures is, however, not directly comparable as the Lohmander and Helles data are the actual modelled damage for the devastating storm in 1981 whereas our data are relative values that are multiplied with further factors to get the damage for a certain storm. The Lohmander and Helles model is also calibrated for a relatively limited area where the range in forest properties is limited and it is therefore not suitable for extrapolation to the target regional scale of our model. While the shape of the responses differs between the two models, it may be noted that they agree on the sign of each relationship.

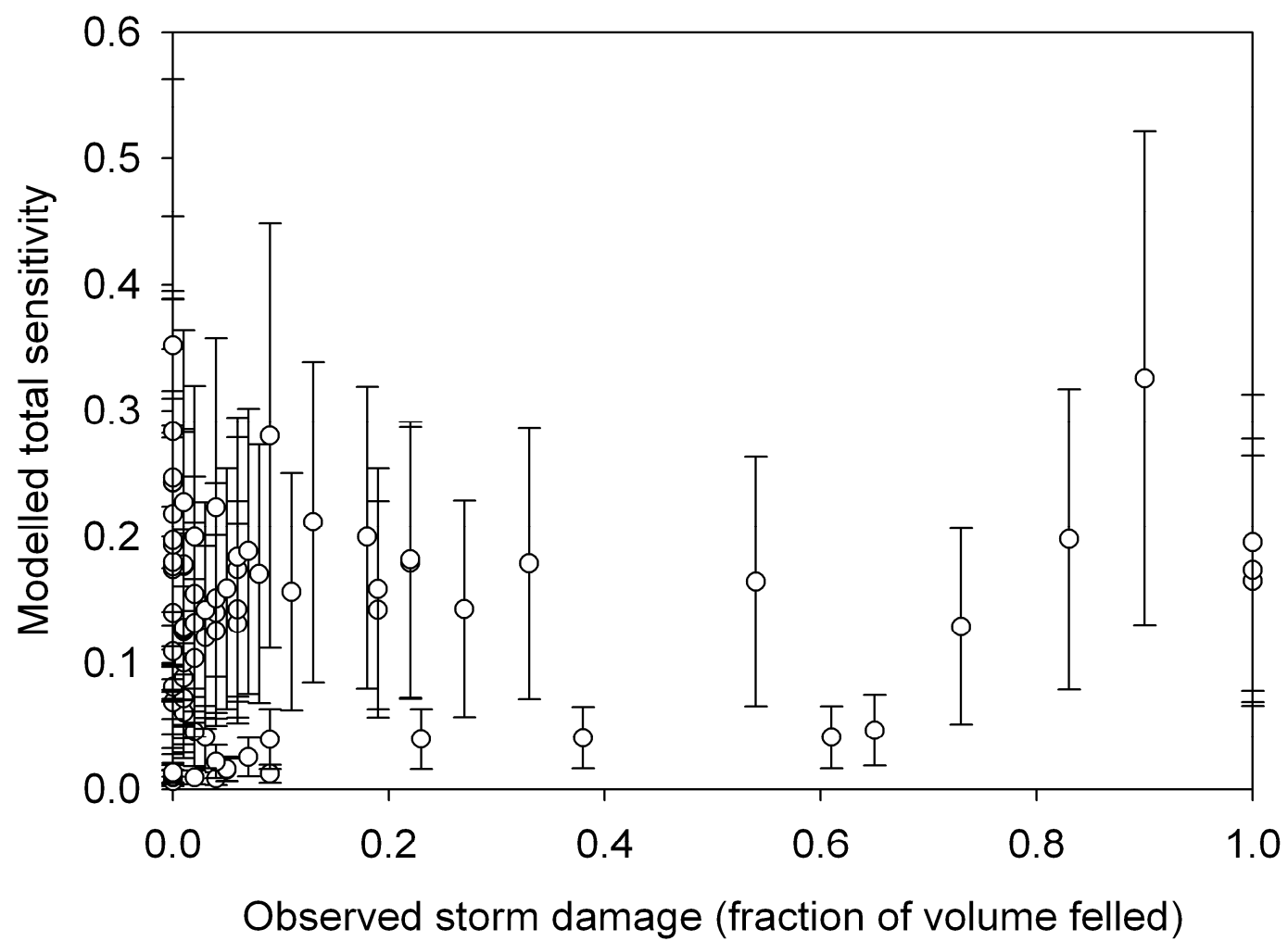

Figure 2. Modelled total sensitivity (EI_patch $\times$ HI_patch $\times$ RSI_patch $\times$ HI_cohort $\times$ SI_cohort) against observed storm damage in the 1969 storm at Tönnersjöheden (data from Persson 1975). In EI_patch EI_gridcell is set to 1 and the min, mean and max of the random factor $\left(f_{\text {RAND }}, 0.25-1\right)$ is shown (see Eq. 8). 

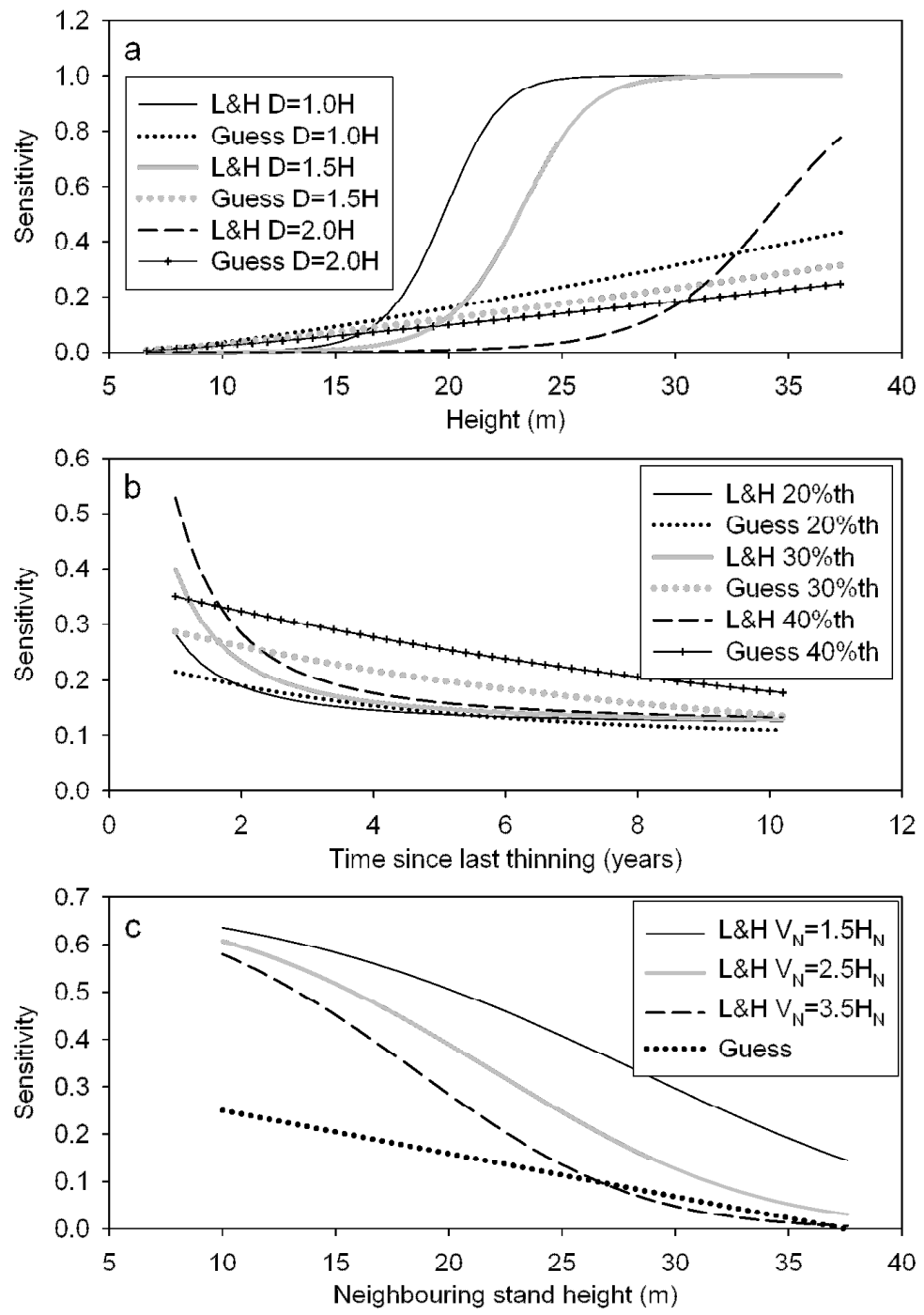

Figure 3. Comparison of the Lohmander \& Helles and the Guess storm model output of storm sensitivity for different forest properties. a) Modelled storm sensitivity as a function of stand height $(\mathrm{H})$ for different diameter $(\mathrm{D}) /$ height relations. b) Modelled storm sensitivity as a function years since last thinning for thinnings with 20, 30 and 40\% removal. c) Modelled storm sensitivity as a function of neighbouring stand height $\left(\mathrm{H}_{\mathrm{N}}\right)$ for different volume $\left(\mathrm{V}_{\mathrm{N}}\right) /$ height relations in the neighbouring stand.

The model's ability to simulate the managed forest in Sweden

There is an increasing trend in both growth and volume of the Swedish forest over the twentieth century (Figure 4) as a result of previous strong exploitation of the forests, improved management, increased atmospheric $\left[\mathrm{CO}_{2}\right]$ and nutrient enrichment due to nitrogen deposition (Solberg et al., 2009; SwedishForestAgency, 2011). Of these factors only the influence of increased $\left[\mathrm{CO}_{2}\right]$ is normally considered in LPJ-GUESS (see e.g. Hickler et al., 2008). The two first factors were taken into account in our simulations by doubling the strength of all thinnings before 1961, after which simulated volume followed the long-term measured trend but the growth trend could not be fully captured (Figure 4). The reason is that the volume trend depends on both growth and harvest. 


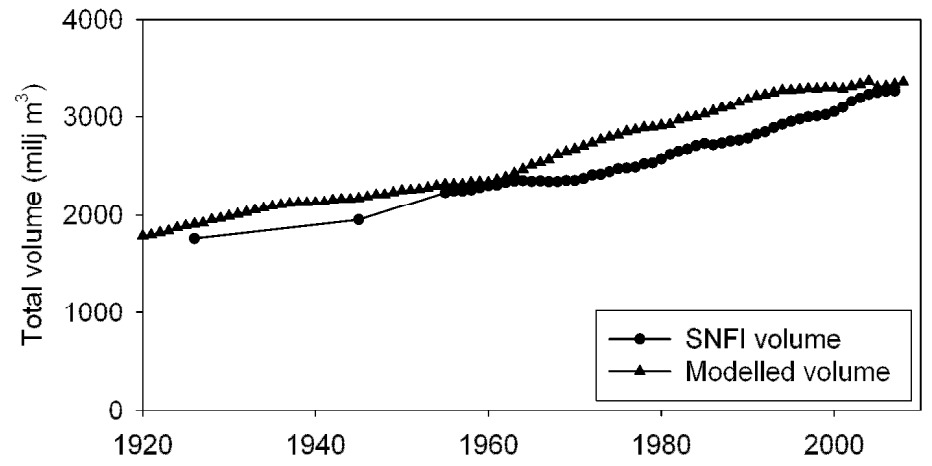

Figure 4. Total volume (above) and 5-year average total harvest and growth (below) for Sweden. Modelled values compared to data from the Swedish national forest inventory (SNFI).

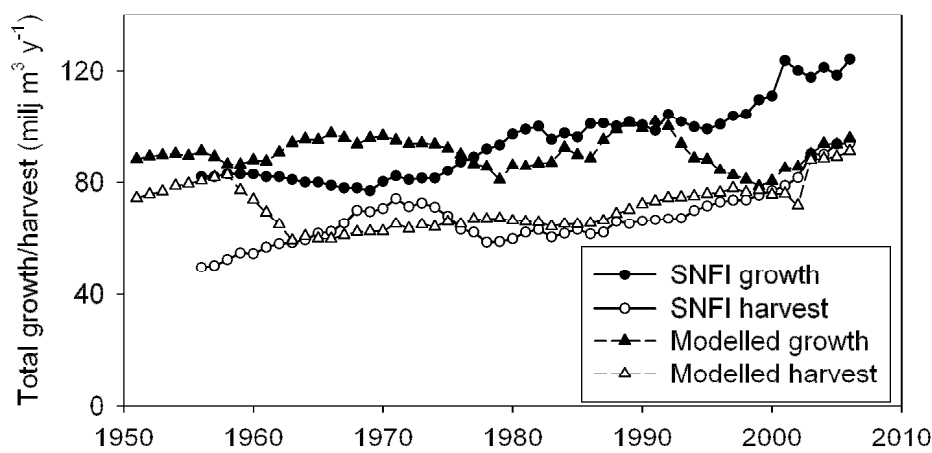

Figure 5. County-level average growth and volume in 2004, modelled values versus data from the Swedish national forest inventory (SNFI). SNFI growth data also include production of self-thinned trees and growth of harvested trees, which makes up for $5-10 \%$ of the difference.

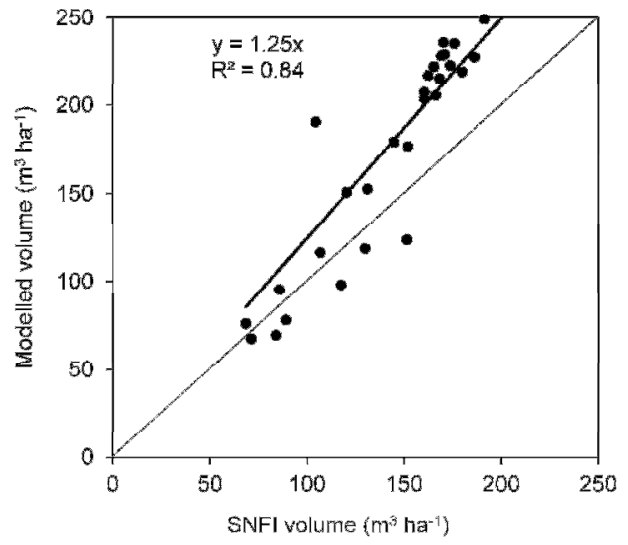


The model successfully simulated variation in growth among counties (slope $=0.84 \mathrm{R}^{2}=$ 0.90, Figure 5), showing that the county specific scaling of the productivity in Eq. 4 worked as intended. SNFI growth data also include production of self-thinned trees and growth of harvested trees, which makes up for 5-10\% of the difference. For volume the relationship was not as good (slope $=1.25 \mathrm{R}^{2}=0.84$, Figure 5), which mainly was a result of an overestimation in southern Sweden, where the average volumes are highest.

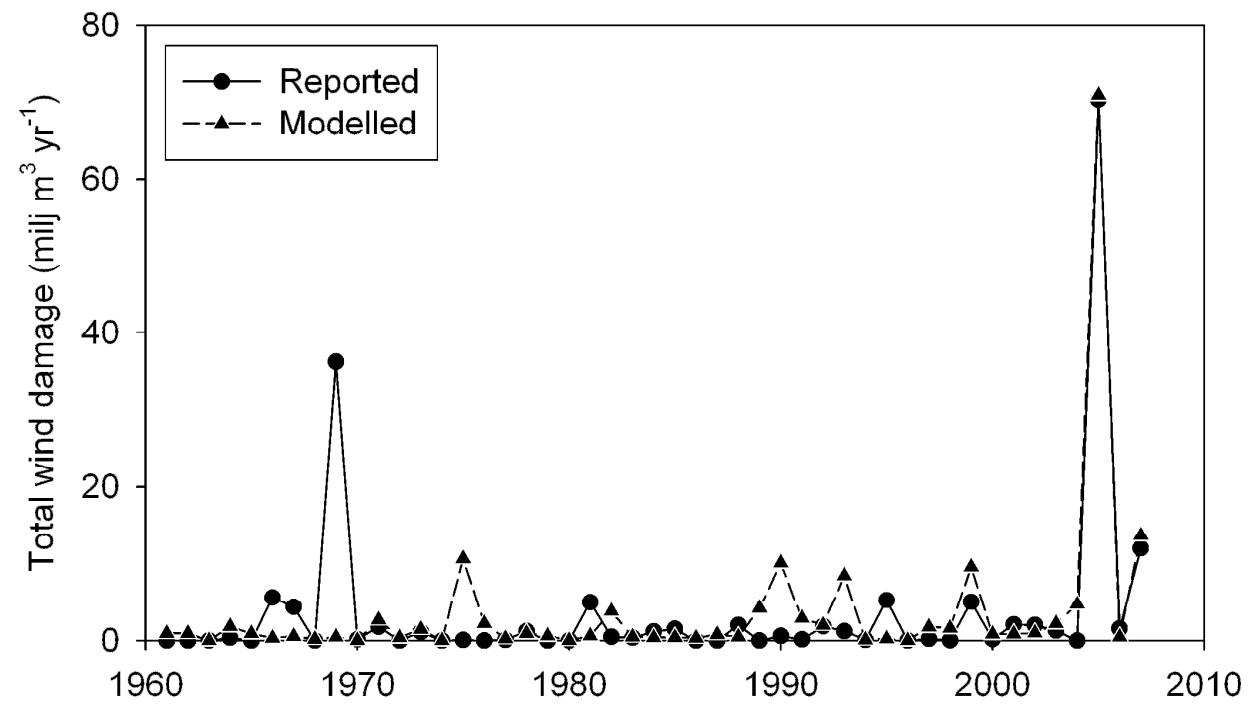

Figure 6. Modelled and reported (Nilsson, 2008; Nilsson et al., 2004) total wind damage in Sweden. The model was calibrated to give the reported total damage in 2005.

\section{Simulation of landscape-level storm damage for Sweden}

Following calibration to damage data for 2005 , the model was able to reproduce damages from the 1999 and 2007 storms, but not the 1969 storm. Substantial damages were also predicted for some years with only minor reported damage (Figure 6). The spatial distribution of damages across Sweden was best described for the 2007 storm $\left(R^{2}=0.60\right)$ and become worse the older the storm was (Figure 7).

Table 3. Sensitivity test of the effective height of broad leafed trees (original value 0.5), parameter $a$ in in Equation 10 (original value 0.30) and parameter $c$ in in Equation 11 (original value 0.70 ). With the different settings the results were compared between predicted and reported grid-cell level yearly wind damage for the 1961-2007 period with regressions, as in Figure 7.

\begin{tabular}{lccc}
\hline & Slope & Intercept & $\mathrm{R}^{2}$ \\
\hline Original & 0.47 & 0.08 & 0.43 \\
Effective height broad leafed: 0.25 & 0.48 & 0.08 & 0.43 \\
Effective height broad leafed: 1.0 & 0.44 & 0.08 & 0.43 \\
$a$ in Eq. 10: 0.15 & 0.35 & 0.06 & 0.44 \\
$a$ in Eq. 10: 0.60 & 0.69 & 0.12 & 0.43 \\
$c$ in Eq. 11: 0.35 & 0.35 & 0.05 & 0.40 \\
$c$ in Eq. 11: 1.0 & 0.55 & 0.10 & 0.44 \\
\hline
\end{tabular}


The sensitivity test on the same data comparison as the uppermost panel in Figure 7 showed relatively small changes in $\mathrm{R}^{2}$ from the original setting, though the parameters were halved or doubled (Table 3). Due to the relative low fraction of broad-leafed trees in Sweden the change in the efficient height had only a minor effect on the slope. Changing $a$ in Equation 10 mainly change the sensitivity (RSI_patch) of not recently thinned patches and the effect on the slope was about half of the relative change in the parameter. Similar results were achieved by changing $c$ in Equation 11 as that will change the sensitivity (FSI_patch) on patches with a small number of frozen days, the parameter could not be changed by $+100 \%$ and the relative change for the "high" setting was therefore smaller.

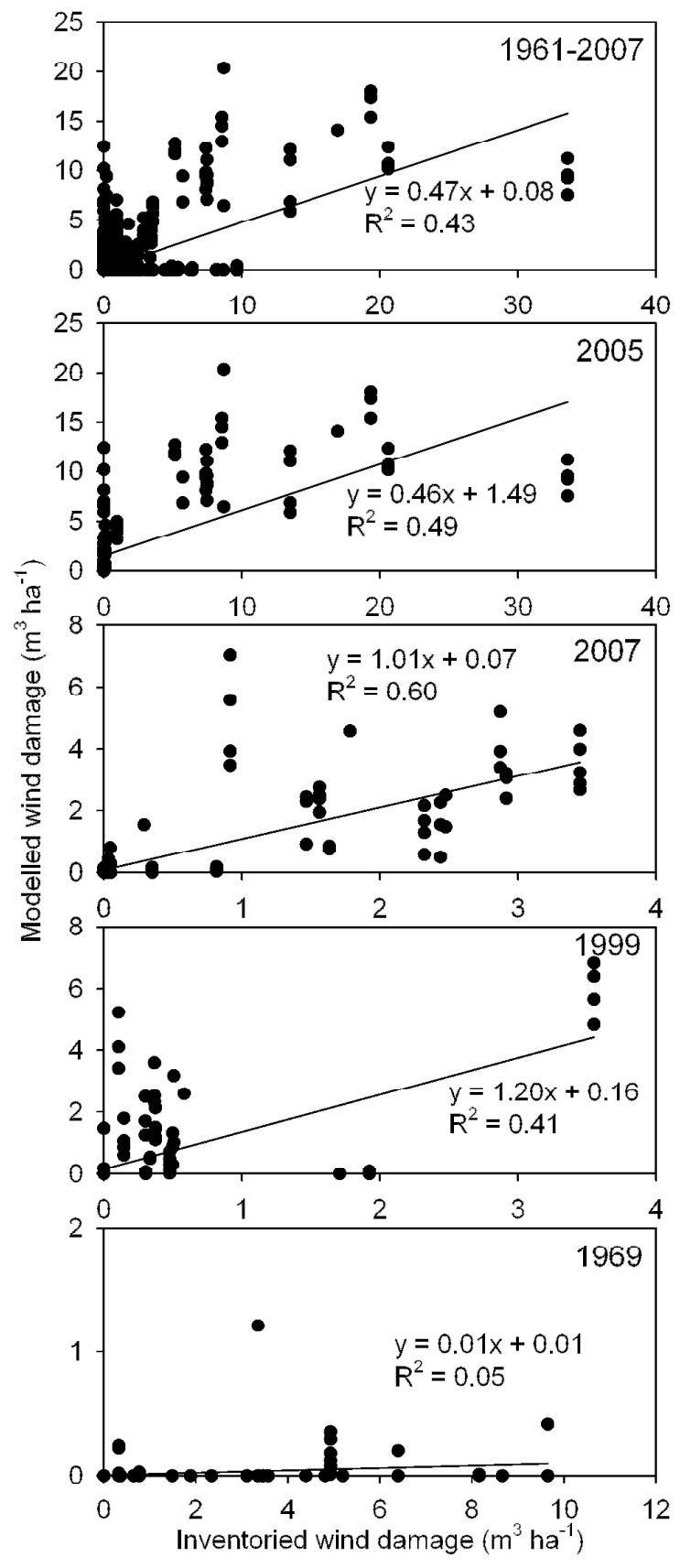

Figure 7. Modelled and reported (Nilsson, 2008; Nilsson et al., 2004) annual average wind damage on grid-cell level for the whole period and for selected years with high levels of inventoried damage. 
The wind damage in Sweden for 1961-2007 has mainly been to the southern part (latitude $<60^{\circ}$, Figure 8 ). The between-year variation is also relatively well described by the model for this area (Figure 8) but if the dominating storm in 2005 is excluded, the strengths of the relationships between simulated and observed damages are strongly reduced in southern Sweden.
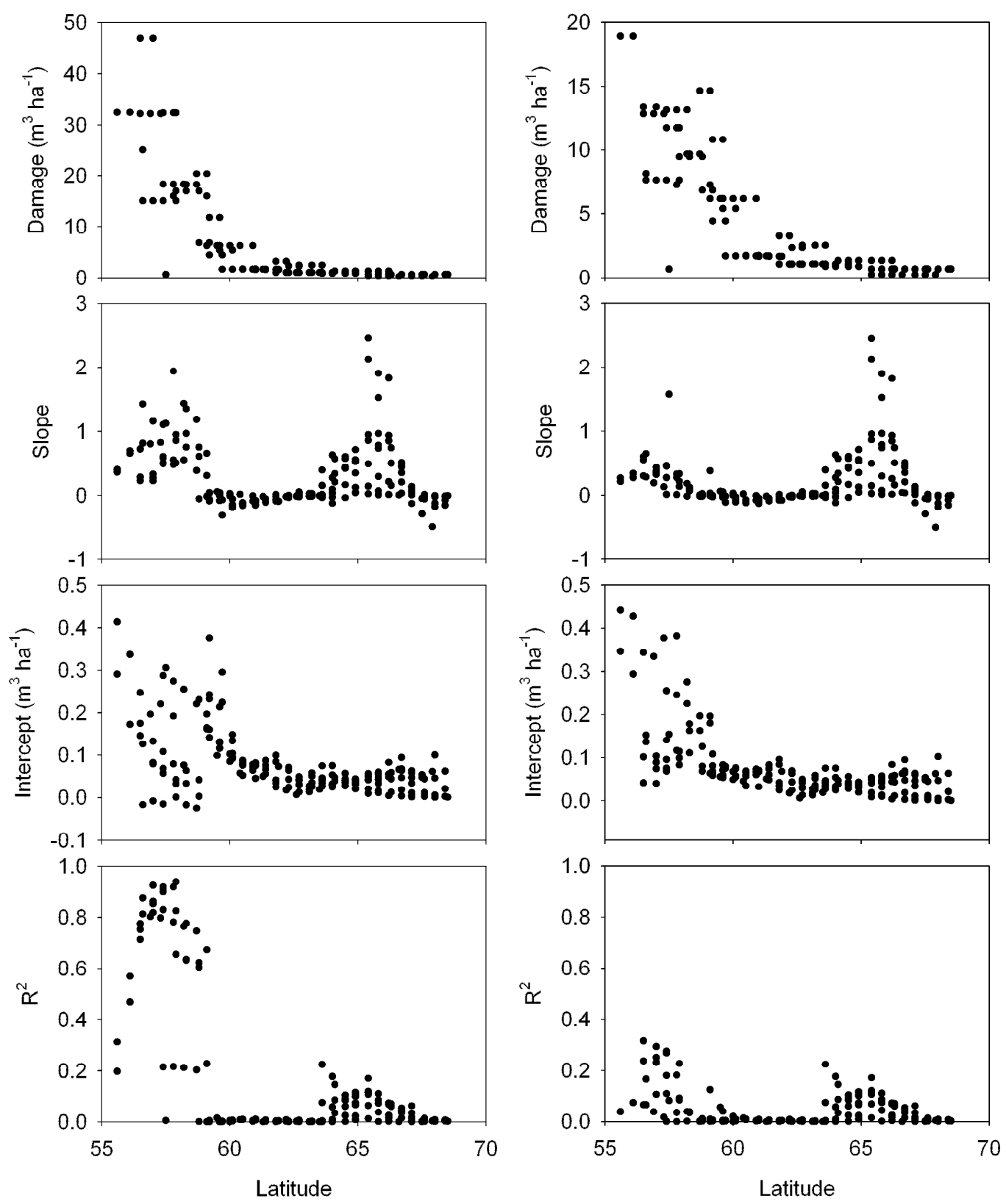

Figure 8. Grid-cell level total inventoried damage 1961-2007 and the grid-cell level statistics for the relation between inventoried and modelled annual damage, plotted against latitude. In the right figures year 2005 has been excluded. 


\section{Discussion}

The wind-damage module has been developed to be applicable to Sweden or regions with similar type of forests. The latter is dictated by the equations that employ parameters related to the dimensions and structure of specific tree species and forests (Equations 7, 9, 12 and 13). By adjusting the relevant parameters the model may well be applicable to other regions, but the robustness should be tested before practical use. The only speciesdependant parameter is $k_{\text {species }}$ in Equation 13, which has to be parameterized if new species are included. LPJ-GUESS was not able to fully capture the trends and variation in standing volume and growth over Sweden (Figure 4-5). A representation of the nitrogen limitation and supply would probably improve the simulation of the growth trend as the deposition varies and a dependency has been shown (Solberg et al., 2009). This is something that we expect to be included in coming versions of LPJ-GUESS. There is also a difference between modelled and inventoried harvested volume, which indicates that it would be possible to improve the simulations by including high-resolution harvest statistics. The finding that the volume in Southern Sweden was overestimated (Figure 5) also implies that the calibration-factor $m$ has to be recalibrated when the model is used in new situations.

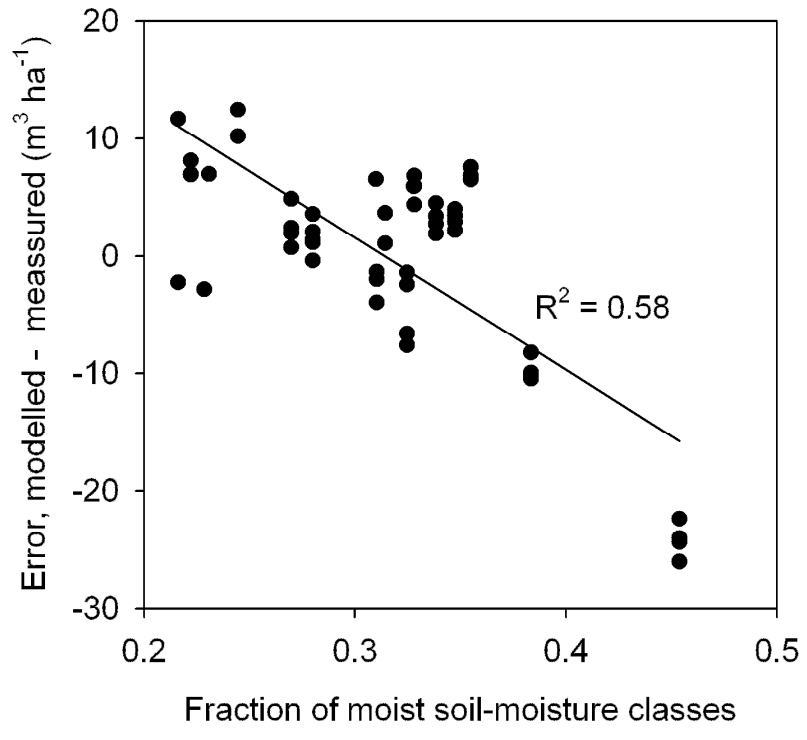

Figure 9. The error of modelled wind damage in 2005 for Southern Sweden (Latitude <60), plotted against the fraction of standing volume on soil moisture classes; mesic-moist, moist and wet. These classes have by definition less than $1 \mathrm{~m}$ to the average ground water level (http://wwwmarkinfo.slu.se/eng/soildes/fukt/skfukt 1.html, accessed 7 July. 2012).

Topography and soil properties are known to be of importance for wind damage but we largely omit their influence, in the interests of keeping the model applicable at the regional scale. In the exposure index, small-scale variation in topography is assumed to be represented by the random factor (Equation 8) but there could also be differences in the general composition of slopes and exposure between grid cells that are not represented. A way to take topography into account could be to compute grid-cell distributions of some type of topographic index based on digital elevation model (DEM) data, and use this distribution instead of the uniform one currently assumed in Equation 8. Lanquaye-Opoku and Mitchell (2005) used a simple index, Topex 2000, which showed 
both positive and negative correlation to locally fitted empirical models. Likewise the study of Scott and Mitchell (2005) showed non-linear relationships to Topex indices. It is therefore not obvious that inclusion of grid-cell specific topography will improve the results significantly. Soil properties are included in both mechanical (Gardiner et al., 2008) and empirical (Scott and Mitchell, 2005) wind damage models. For the 2005 storm, which occurred under mostly unfrozen soil conditions, the simulated errors were correlated to the county-level average fraction of moist forest (Figure 9). A potential to improve the model by including information about soil moisture class distribution in the root stability index is evident but no correlation was found for the other years and it was therefore not included. Soil moisture level was also positively related to damage after storm Kyrill in north-western Germany in 2007 (Klaus et al., 2011) and hydrology related parameters are common in mechanistic models (Gardiner et al., 2008).

The storm module has been implemented with yearly values of wind load, an index of frozen soil and applied the damage in the end of each year together with the other vegetation dynamics. This is a simplification that can cause some mismatch of the timing, both between wind load and the frozen soil index and between wind load and the applied damage to the vegetation dynamics (see supplementary content S2). If the aim was to simulate the biology of the vegetation dynamics and still use an annual implementation it would be better to calculate wind load seasonally instead of yearly as wind damage in October or March will have about the same impact on the forest. In this study the aim was, however, to present the model and compare the result to inventoried data that have been reported on an annual basis. In supplementary content S3 we show that the accumulated damage will change just slightly, though the timing often shifts, when using seasonal wind-load data.

The module's ability to predict stand level sensitivity (Figure 2) was limited. The reason for this mismatch could be either a poor representation of the wind sensitivity in the model, or that the dependency of damage to a stand's position in the landscape and its spatial relationship to other stands is even larger than the $0.25-1.0$ random factor in Eq. 8 suggests. It should, however, be noted that the data only included stands with a dominant height $>15$ meter and therefore considered "wind sensitive". Persson (1975) showed that much of the variability could be explained by a detailed analysis of the exposure but this is difficult to express as a single index. However, a low degree of explanation is not unusual for empirical regression models (e.g. Klaus et al., 2011; Schütz et al., 2006), though there are also examples with good predictions (Lanquaye-Opoku and Mitchell, 2005; Scott and Mitchell, 2005). The storm module takes within-stand characteristics (RSI_patch, HI_cohort and AI_cohort) and average landscape level exposure aspects (EI_gridcell and HI_patch) into account, but as the simulated patches have no explicit location or relation to each other they carry no information about direct exposure or local wind fields. WINDA, a detailed modelling system that takes these aspects into account, was able to correctly identify only 9 of 24 damaged stands (out of 305 in total) for a storm in southern Sweden in 1993 (Blennow and Sallnäs, 2004). Schütz et al. (2006) suggest that the stochastic nature of wind damage to spruce is related to repeated destructive gusts that occur very randomly. The storm is simulated as a single shot whereas in reality a stand that has started to be damaged will be more and more sensitive 
as the damage progress. This could also be a reason why the variation in observed storm damage is higher than the sensitivity (Figure 2). The same u-shaped damage pattern has also been observed, e.g., in Switzerland after the 1999 storm (Schütz et al., 2006).

On the regional scale LPJ-GUESS was able to explain 41-60\% of the variation in gridcell storm damage of the most recent storms (Figure 7). Even though this level of explanatory power is not high, we suggest that it represents a good first attempt at modelling forest wind damage dynamically at the regional scale. But it is clear that the predisposed sensitivity is of minor importance compared to the triggering factors; i.e. occurrence of frozen soil and, most important, wind load. Wind load itself explained 18\% of the variation for the whole 1961-2007 period and for some of the stormy years it was actually more closely related to the observed damage than the modelled damage was. However, the sensitivity analysis (Table 3) did not indicate that any of the more uncertain parameters confounded the predisposed sensitivity, which could have been the case if the model was based on some wrong assumptions. The increase in explanation over time is not surprising as the observation systems that deliver the underlying data to ERA40 have been incrementally improved over recent years (http://www.ecmwf.int/research/era/ERA40/Data_Services/section3.html, accessed 7 July 2012) and also the quality of the reported wind damage has improved. There is also uncertainty in the RCA_ERA40 wind data. On a European scale the seasonal mean features of the circulation patterns are closely captured by RCA3 (Kjellström et al., 2011) but the ability to reproduce the fine scale pattern of the most extreme wind events is more uncertain as there are no wind observations that are suitable for validation (Nikulin et al., 2011). Problems with ERA40 wind speed data have been reported before. Schelhaas et al. (2010) found low correlations between country-specific wind damage data and ERA40 wind speed data. Smits et al. (2005) got opposing trends in windiness for the same area using ERA40 data and high-quality station data.

\section{Conclusions}

Like in other studies, the explanatory power of the model at the stand level was low but it was able to distribute the damage at a regional level reasonable well. There could be a potential to improve the model by using soil type, soil moisture or topographic information.

By implementing wind damage with mechanical features in a dynamical vegetation model we have got an efficient tool, which can be used with different options of management, tree species and climate scenarios to address future storm-damage risk. It would be feasible to adapt the model to describe other damage agents of forests such as bark beetle attacks that often occur in connection with the wind throw of trees. 


\section{Acknowledgement}

This study was supported by the Foundation for Strategic Environmental Research programme Mistra-SWECIA, the Swedish Research Council FORMAS (project 2010822 ) and the EU project MOTIVE ('Models for adaptive forest management', grant No. 226544). We also thank Barry Gardiner, Forest Research, UK, for letting us test the ForestGales model in an attempt to improve the study.

\section{References}

Blennow, K., Andersson, M., Sallnäs, O., Olofsson, E., 2010. Climate change and the probability of wind damage in two Swedish forests. For. Ecol. Manage. 259, 818830.

Blennow, K., Sallnäs, O., 2004. WINDA - a system of models for assessing the probability of wind damage to forest stands within a landscape. Ecol. Model. 175, 87-99.

Burton, J.D., Smith, D.M., 1972. Guying to prevent windsway influences loblolly pine growth and wood properties. USDA Forest Service research paper SO. S0-80.

Farrar, J.L., 1961. Longitudinal variations in the thickness of the annual ring. Forestry Chronicle 37, 323-331.

Gardiner, B., Blennow, K., Carnus, J.-C., Fleischer, P., Ingemarson, F., Landman, G., Lindner, M., Marzano, M., Nicoll, B., Orazio, C., Peyron, J.-L., Reviron, M.-P., Schalhaas, M.-J., Schuck, A., Spielmann, M., Usbeck, T., 2010. Destructive storms in European forests: past and forthcoming impacts. Final report to European Commission - DG Environment, European Forest Institute.

Gardiner, B., Byrne, K., Hale, S., Kamimura, K., Mitchell, S.J., Peltola, H., Ruel, J.C., 2008. A review of mechanistic modelling of wind damage risk to forests. Forestry 81, 447-463.

Gerten, D., Schaphoff, S., Haberlandt, U., Lucht, W., Sitch, S., 2004. Terrestrial vegetation and water balance - hydrological evaluation of a dynamic global vegetation model. J. Hydrol. 286, 249-270.

Hagner, M., 1996. Liberich - Liberation thinning combined with enrichment planting Guide for practical application of a management system. Working papers 113, Department of Silviculture, Umeå.

Hale, S.E., 2003. The effect of thinning intensity on the below-canopy light environment in a Sitka spruce plantation. For. Ecol. Manage. 179, 341-349.

Hickler, T., Smith, B., Prentice, I.C., Mjöfors, K., Miller, P., Arneth, A., Sykes, M.T., 2008. CO2 fertilization in temperate FACE experiments not representative of boreal and tropical forests. Global Change Biol. 14, 1531-1542.

Hoyos, C.D., Agudelo, P.A., Webster, P.J., Curry, J.A., 2006. Deconvolution of the factors contributing to the increase in global hurricane intensity. Science 312, 9497.

Kjellström, E., Nikulin, G., Hansson, U., Strandberg, G., Ullerstig, A., 2011. 21 st century changes in the European climate: uncertainties derived from an ensemble of regional climate model simulations. Tellus A 63, 24-40. 
Klaus, M., Holsten, A., Hostert, P., Kropp, J.P., 2011. Integrated methodology to assess windthrow impacts on forest stands under climate change. For. Ecol. Manage. 261, 1799-1810.

Klawa, M., Ulbrich, U., 2003. A model for the estimation of storm losses and the identification of severe winter storms in Germany. Nat. Hazards Earth Syst. Sci. 3, 725-732.

Kloster, S., Mahowald, N.M., Randerson, J.T., Thornton, P.E., Hoffman, F.M., Levis, S., Lawrence, P.J., Feddema, J.J., Oleson, K.W., Lawrence, D.M., 2010. Fire dynamics during the 20th century simulated by the Community Land Model. Biogeosciences 7, 1877-1902.

Koca, D., Smith, B., Sykes, M.T., 2006. Modelling regional climate change effects on potential natural ecosystems in Sweden. Clim. Change 78, 381-406.

Kohnle, U., Gauckler, S., 2003. Vulnerability of forests to storm damage in a forest district of south-western Germany situated in the periphery of the 1999 storm (Lothar), in: Ruck, B., Kottmeier, C., Mattheck, C., Quine, C., Wilhelm, G. (Eds.), Wind effects on trees, University of Karlsruhe, Germany.

Lanquaye-Opoku, N., Mitchell, S.J., 2005. Portability of stand-level empirical windthrow risk models. For. Ecol. Manage. 216, 134-148.

Lehsten, V., Harmand, P., Palumbo, I., Arneth, A., 2010. Modelling burned area in Africa. Biogeosciences 7, 3199-3214.

Lindroth, A., 1993. Aerodynamic and canopy resistance of short-rotation forest in relationship to leaf area index and climate. Boundary-Layer Meteorol. 66, 265279.

Lindroth, A., Lagergren, F., Grelle, A., Klemedtsson, L., Langvall, O., Weslien, P., Tuulik, J., 2009. Storms can cause Europe-wide reduction in carbon sink. Global Change Biol. 15, 346-355.

Lohmander, P., Helles, F., 1987. Windthrow probability as a function of stand characteristics and shelter. Scand. J. For. Res. 2, 227-238.

Miller, P.A., Giesecke, T., Hickler, T., Bradshaw, R.H.W., Smith, B., Seppa, H., Valdes, P.J., Sykes, M.T., 2008. Exploring climatic and biotic controls on Holocene vegetation change in Fennoscandia. J. Ecol. 96, 247-259.

Monteith, J.L., Unsworth, M.H., 1990. Principals of environmental physics, 2nd ed. Edward Arnold, London, 291 pp.

Näslund, M., 1971. Nytt material för skoglig produktionsforskning ( New material for forest yield research). Stud. For. Suec. 89, 124 pp.

Ni Dhubhain, A., Walshe, J., Bulfin, M., Keane, M., Mills, P., 2001. The initial development of a windthrow risk model for Sitka spruce in Ireland. Forestry 74, 161-170.

Nielsen, C.C.N., 1995. Recommendations for stabilisation of Norway spruce stands based on ecological surveys, in: Coutts, M.P., Grace, J. (eds.), Wind and Trees.

Cambridge Univeristy Press, pp. 424-435.

Nikulin, G., Kjellström, E., Hansson, U., Strandberg, G., Ullerstig, A., 2011. Evaluation and future projections of temperature, precipitation and wind extremes over Europe in an ensemble of regional climate simulations. Tellus A 63, 41-55. 
Nilsson, C., 2008. Windstorms in Sweden - variations and impacts, doctoral thesis, Department of Physical Geography and Ecosystems Analysis. Lund University, Lund, p. 169.

Nilsson, C., Stjernquist, I., Bärring, L., Schlyter, P., Jönsson, A.M., Samuelsson, H., 2004. Recorded storm damage in Swedish forests 1901-2000. For. Ecol. Manage. 199, 165-173.

Oleskog, G., Nilson, K., Wikberg, P.-E., 2008. Kontinuitetsskogar och kontinuitetsskogsbruk, Slutrapport för delprojekt skötsel - hyggesfritt skogsbruk. Rapport 22, Swedish Forest Agency, Jönköping, 79 pp.

Oliver, H.R., Mayhead, G.J., 1974. Wind measurements in a pine forest during a destructive gale. Forestry 47, 185-194.

Peltola, H., Kellomäki, S., Hassinen, A., Granander, M., 2000. Mechanical stability of Scots pine, Norway spruce and birch: an analysis of tree-pulling experiments in Finland. For. Ecol. Manage. 135, 143-153.

Peltola, H., Kellomäki, S., Väisänen, H., 1999a. Model computations of the impact of climatic change on the windthrow risk of trees. Clim. Change 41, 17-36.

Peltola, H., Kellomäki, S., Väisänen, H., Ikonen, V.P., 1999b. A mechanistic model for assessing the risk of wind and snow damage to single trees and stands of Scots pine, Norway spruce, and birch. Can. J. For. Res. 29, 647-661.

Persson, P., 1975. Windthrow in forests - It's causes and the effect of forestry measures, Department of Forest Yield Research, No 36. Royal College of Forestry, Stockholm, 294 pp.

Prentice, I.C., Sykes, M.T., Cramer, W., 1993. A simulation model for the transient effects of climate change on forest landscapes. Ecol. Model. 65, 51-70.

Rudnicki, M., Mitchell, S.J., Novak, M.D., 2004. Wind tunnel measurements of crown streamlining and drag relationships for three conifer species. Can. J. For. Res. 34, 666-676.

Samuelsson, P., Jones, C.G., Willen, U., Ullerstig, A., Gollvik, S., Hansson, U., Jansson, C., Kjellström, E., Nikulin, G., Wyser, K., 2011. The Rossby Centre Regional Climate model RCA3: model description and performance. Tellus A 63, 4-23.

Schelhaas, M.-J., Hengeveld, G., Moriondo, M., Reinds, G.J., Kundzewicz, Z.W., ter Maat, H., Bindi, M., 2010. Assessing risk and adaptation options to fires and windstorms in European forestry. Mitig. Adapt. Strateg. Glob. Chang. 15, 681701.

Schelhaas, M.-J., Nabuurs, G.-J., Schuck, A., 2003. Natural disturbances in the European forests in the 19th and 20th centuries. Global Change Biol. 9, 1620-1633.

Schütz, J.-P., Götz, M., Schmid, W., Mandallaz, D., 2006. Vulnerability of spruce (Picea abies) and beech (Fagus sylvatica) forest stands to storms and consequences for silviculture. Eur. J. For. Res. 125, 291-302.

Scott, R.E., Mitchell, S.J., 2005. Empirical modelling of windthrow risk in partially harvested stands using tree, neighbourhood, and stand attributes. For. Ecol. Manage. 218, 193-209.

Seidl, R., Fernandes, P.M., Fonseca, T.F., Gillet, F., Jönsson, A.M., Merganičová, K., Netherer, S., Arpaci, A., Bontemps, J.-D., Bugmann, H., Ramon GonzàlezOlabarria, J., Lasch, P., Meredieu, C., Moreira, F., Schelhaas, M.-J., Mohren, F., 
2011. Modelling natural disturbances in forest ecosystems: a review. Ecol. Model. 222, 903-924.

Shugart, H.H., 1984. A theory of forest dynamics. The ecological implications of forest succession models. Springer, New York, 278 pp.

Sitch, S., Smith, B., Prentice, I.C., Arneth, A., Bondeau, A., Cramer, W., Kaplans, J.O., Levis, S., Lucht, W., Sykes, M.T., Thonicke, K., Venevsky, S., 2003. Evaluation of ecosystem dynamics, plant geography and terrestrial carbon cycling in the LPJ dynamical global vegetation model. Global Change Biol. 9, 161-185.

Skogsstyrelsen, 1989a. Gallringsmallar Norra Sverige. Tryckeri AB Småland, Jönköping. Skogsstyrelsen, 1989b. Gallringsmallar Södra Sverige. Tryckeri AB Småland, Jönköping.

Smith, B., Prentice, I.C., Sykes, M.T., 2001. Representation of vegetation dynamics in the modelling of terrestrial ecosystems: comparing two contrasting approaches within European climate space. Global Ecol. Biogeogr. 10, 621-637.

Smits, A., Tank, A., Können, G.P., 2005. Trends in storminess over the Netherlands, 1962-2002. Int. J. Climatol. 25, 1331-1344.

Solberg, S., Dobbertin, M., Reinds, G.J., Lange, H., Andreassen, K., Fernandez, P.G., Hildingsson, A., de Vries, W., 2009. Analyses of the impact of changes in atmospheric deposition and climate on forest growth in European monitoring plots: A stand growth approach. For. Ecol. Manage. 258, 1735-1750.

SwedishForestAgency, 2002. Swedish Statistical Yearbook of Forestry 2002. Swedish Forest Agency, Jönköping.

SwedishForestAgency, 2003. Swedish Statistical Yearbook of Forestry 2003. Swedish Forest Agency, Jönköping.

SwedishForestAgency, 2007. Swedish Statistical Yearbook of Forestry 2007. Swedish Forest Agency, Jönköping.

SwedishForestAgency, 2008. Swedish Statistical Yearbook of Forestry 2008. Swedish Forest Agency, Jönköping.

SwedishForestAgency, 2011. Swedish Statistical Yearbook of Forestry 2011. Swedish Forest Agency, Jönköping.

Valinger, E., Fridman, J., 1999. Models to assess the risk of snow and wind damage in pine, spruce, and birch forests in Sweden. Environ. Manage. 24, 209-217.

Valinger, E., Fridman, J., 2011. Factors affecting the probability of windthrow at stand level as a result of Gudrun winter storm in southern Sweden. For. Ecol. Manage. 262, 398-403.

Zaehle, S., Sitch, S., Prentice, I.C., Liski, J., Cramer, W., Erhard, M., Hickler, T., Smith, B., 2006. The importance of age-related decline in forest NPP for modeling regional carbon balances. Ecol. Appl. 16, 1555-1574.

Zeng, H.C., Garcia-Gonzalo, J., Peltola, H., Kellomäki, S., 2010. The effects of forest structure on the risk of wind damage at a landscape level in a boreal forest ecosystem. Ann. Forest Sci. 67, Article 111. 


\section{Supplementary content}

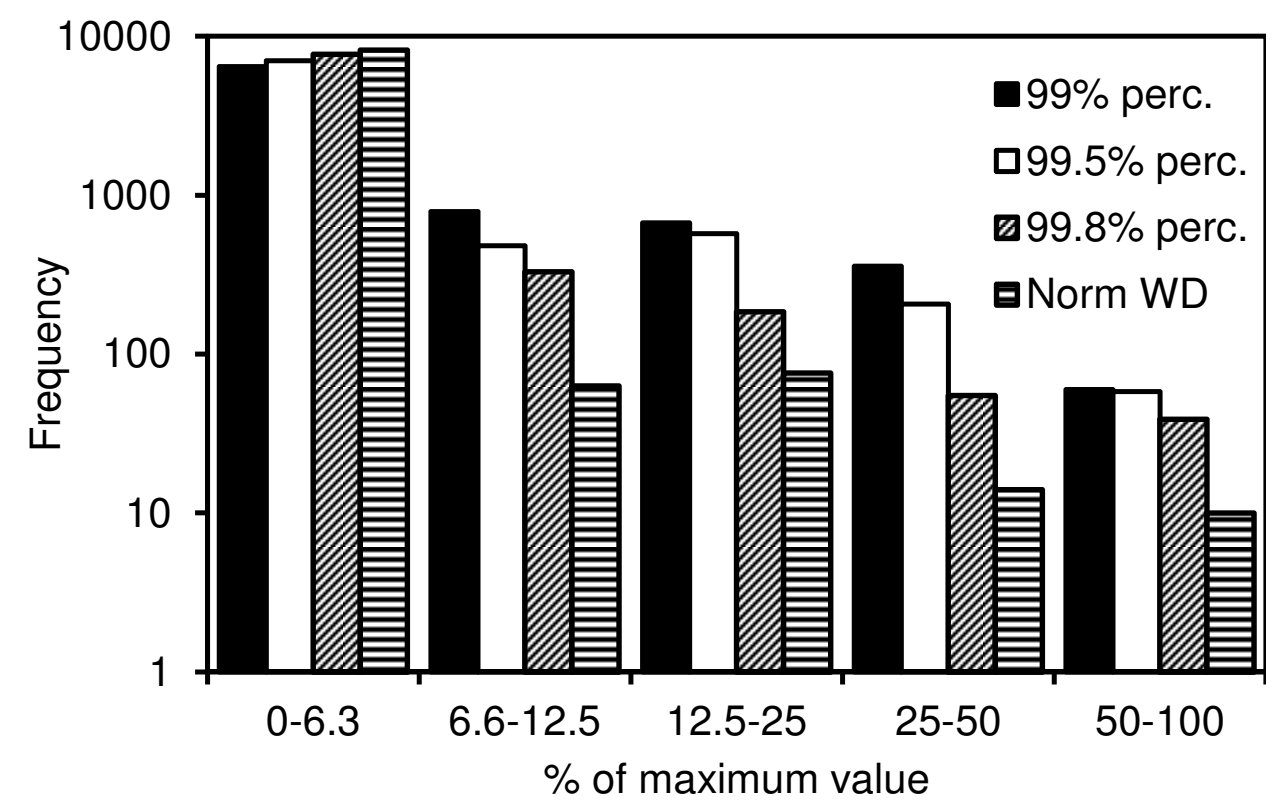

S1. Logarithmic histogram of the distribution of the yearly wind load data calculated with three different wind percentiles, and wind damage that has been normalized with the predisposed wind sensitivity. The five classes are divided relative to the respective variable's maximum value. As seen here the 99.8 percentile show a more similar pattern than the 99.5 percentile that was used and the same was found for regressions. The reason why we chose the 99.5 percentile is that there are a lot of storms that with only cause minor wind throw to a limited area and that the reporting of these events has been very inconsistent over time in Sweden (Nilsson, C., 2008. Windstorms in Sweden - variations and impacts, doctoral thesis, Department of Physical Geography and Ecosystems Analysis. Lund University, Lund, 169 pp). 

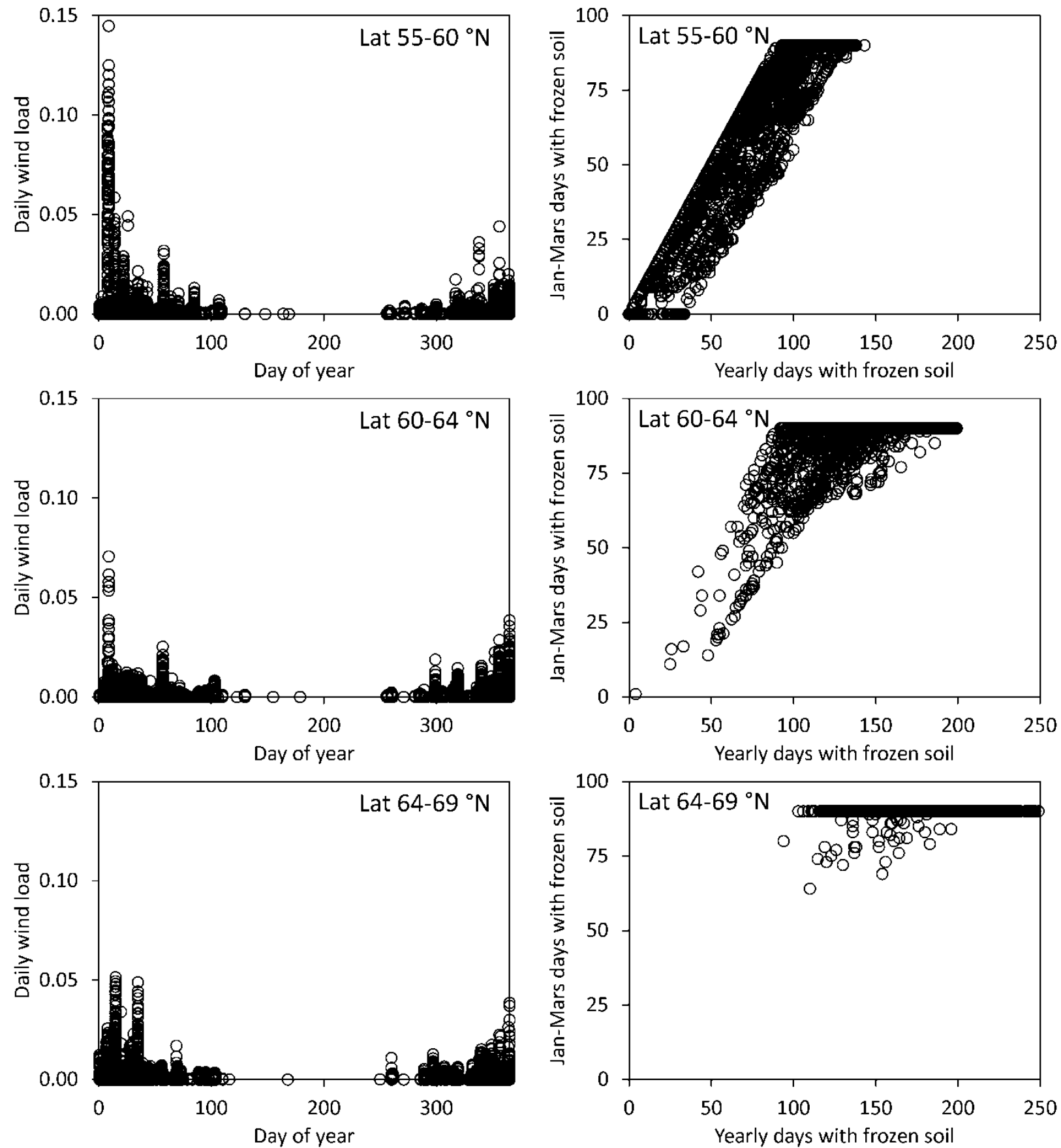

S2. Wind load and frozen day variation for 1961-2008. Left figures, daily wind load (Eq. 6) $>0$ against day of year for three latitudinal regions. Right figures, number of days with frozen soil in January to March (which is what is used in the frozen soil index, Eq. 11), against the total number of frozen days of a year. 


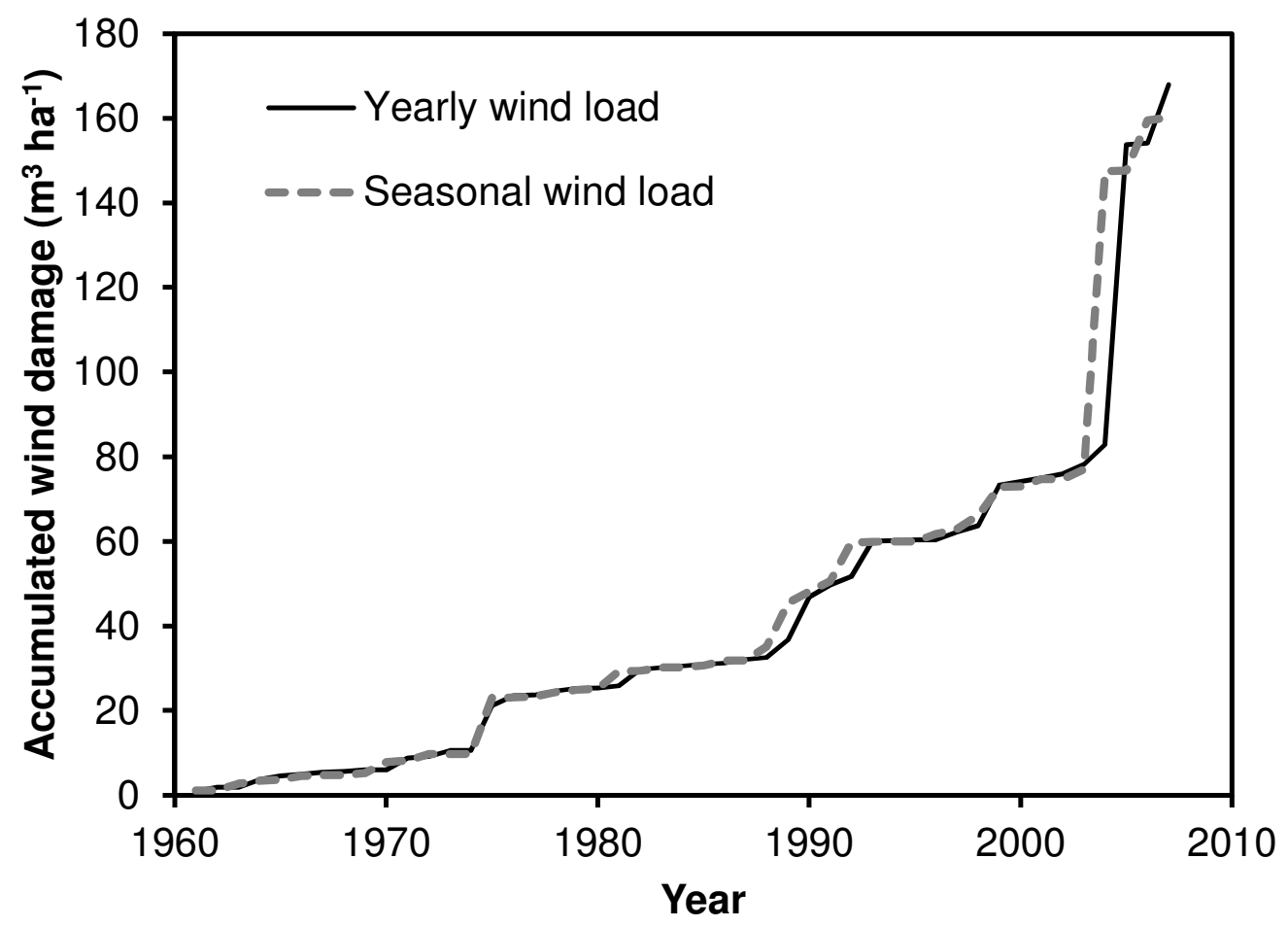

S3. Accumulated total wind damage for Sweden 1961-2008 simulated either with yearly (Jan-Dec) or seasonal (May-Apr +1 year) wind load data. 